\title{
Digested Ara h 1 Loses Sensitizing Capacity When Separated into Fractions
}

Bøgh, Katrine Lindholm; Barkholt, Vibeke; Rigby, Neil M.; Mills, E. N. Clare; Madsen, Charlotte Bernhard

Published in:

Journal of Agricultural and Food Chemistry

Link to article, DOI:

10.1021/jf2052306

Publication date:

2012

Document Version

Publisher's PDF, also known as Version of record

Link back to DTU Orbit

Citation (APA):

Bøgh, K. L., Barkholt, V., Rigby, N. M., Mills, E. N. C., \& Madsen, C. B. (2012). Digested Ara h 1 Loses

Sensitizing Capacity When Separated into Fractions. Journal of Agricultural and Food Chemistry, 60(11), 29342942. https://doi.org/10.1021/jf2052306

\section{General rights}

Copyright and moral rights for the publications made accessible in the public portal are retained by the authors and/or other copyright owners and it is a condition of accessing publications that users recognise and abide by the legal requirements associated with these rights.

- Users may download and print one copy of any publication from the public portal for the purpose of private study or research.

- You may not further distribute the material or use it for any profit-making activity or commercial gain

- You may freely distribute the URL identifying the publication in the public portal 


\title{
Digested Ara h 1 Loses Sensitizing Capacity When Separated into Fractions
}

\author{
Katrine L. Bøgh, ${ }^{* \dagger}$ Vibeke Barkholt, ${ }^{\dagger}$ Neil M. Rigby, ${ }^{\S}$ E. N. Clare Mills, ${ }^{\S}, \|$ and Charlotte B. Madsen ${ }^{\dagger}$ \\ ${ }^{\dagger}$ National Food Institute, Division of Toxicology and Risk Assessment, Technical University of Denmark, Mørkhøj Bygade 19, \\ DK-2860 Søborg, Denmark \\ ${ }^{\ddagger}$ Department of Systems Biology, Enzyme and Protein Chemistry, Technical University of Denmark, Søltoft Plads, \\ Building 224, DK-2800 Kgs. Lyngby, Denmark \\ ${ }^{\S}$ Institute of Food Research, Biochemistry, Norwich Research Park, Colney, Norwich, NR4 7UA, United Kingdom
}

ABSTRACT: The major peanut allergen Ara $\mathrm{h} 1$ is an easily digestible protein under physiological conditions. The present study revealed that pepsin digestion products of Ara $\mathrm{h} 1$ retained the sensitizing potential in a Brown Norway rat model, while this sensitizing capacity was lost by separating the digest into fractions by gel permeation chromatography. Protein chemical analysis showed that the peptide composition as well as the aggregation profiles of the fractions of Ara h 1 digest differed from that of the whole pool. These results indicate that the sensitizing capacity of digested Ara $\mathrm{h} 1$ is a consequence of the peptides being in an aggregated state resembling the intact molecule or that most peptides of the digests need to be present in the same solution, having a synergistic or adjuvant effect and thereby augmenting the immune response against other peptides.

KEYWORDS: Ara h 1, digestion, animal model, food allergy, peptides, aggregation

\section{INTRODUCTION}

Food allergy most often involves an allergen-specific $\operatorname{IgE}$ antibody-mediated immunologic response. It is an adverse reaction to an otherwise harmless food or food component that involves an abnormal response of the immune system to specific food proteins. One of the major unanswered questions in food allergy research is what makes a protein a food allergen. Yet, no definite answer to this exists. However, one of the hypotheses has been that for a protein to be a food allergen, it must survive the digestion process through the gastrointestinal tract, to reach the immune system as an intact protein or as large peptide fragments. ${ }^{1,2}$ The first systematic assessment of food allergen digestibility was conducted in 1996 by Astwood et al. ${ }^{3}$ They showed that in general food allergens were resistant to pepsin digestion, whereas nonallergenic proteins were more easily digested. Since this, several studies examining the correlation between resistance to digestion and allergenicity have been made, where the correlation between stability and allergenicity was less clear. ${ }^{4-10}$ However, it may still be reasonable to think that proteins being resistant or at least partially resistant to digestion have an increased probability of reaching the intestinal mucosa in a form that is sufficiently immunologically active to sensitize the mucosal immune system and be sufficient in size to retain the ability to cross-link two IgE molecules and thereby elicit an allergic reaction. The stability to digestion is for those reasons also recommended for use in the safety assessment of newly introduced proteins in genetically modified foods based on a decision tree or a weight of evidence approach, which includes, among a variety of tests, the assessment of resistance to digestion by pepsin. ${ }^{11-13}$ However, while pepsin stability as a part of an allergenicity assessment would still seem reasonable for the purpose of safety evaluation of most food proteins, we now know that for some allergenic proteins, this approach would be misleading. The milk allergen $\beta$-casein $(\operatorname{Bos} \mathrm{d} 8)^{7,14,15}$ as well as the peanut allergen Ara h $1^{9,10}$ have several times been shown to be easily digestible food allergens.

Peanut allergy is one of the most common and serious types of IgE-mediated food allergies in terms of persistency and severity ${ }^{16,17}$ and seems to be an increasing problem in the western world. ${ }^{18,19}$ The peanut protein Ara $\mathrm{h} 1$, which is a major allergen, ${ }^{20,21}$ is a $7 \mathrm{~S}$ globulin protein belonging to the cupin superfamily of allergens. ${ }^{22}$ Ara $\mathrm{h} 1$ is a homotrimeric protein, consisting of $63.5 \mathrm{kDa}$ large subunits, ${ }^{20}$ held together by hydrophobic interactions between amino acids at monomer-monomer contact points. ${ }^{23,24}$ Ara $\mathrm{h} 1$ is a readily digestible allergen, being digested to small peptide fragments by gastroduodenal digestion. ${ }^{9,10}$ Even though Ara $\mathrm{h} 1$ is a labile protein, Eiwegger et al. ${ }^{9}$ and Bøgh et al. ${ }^{10}$ showed that the digestion products of Ara $\mathrm{h} 1$ retain allergenic potential, being able to sensitize as well as elicit allergic reactions. These studies indicated that aggregation of peptides may play a major role in maintaining allergenic activity. Epitope mapping studies of this protein have suggested both linear ${ }^{21}$ and conformational ${ }^{25}$ IgEbinding epitopes, at least some of which are able to survive the digestion process. ${ }^{10,26}$

Peptides need to have a certain size to be allergenic, but the exact lower molecular weight (MW) size limit is not known. Yet, many suggestions for such a lower MW size limit have been presented, ${ }^{11,27-31}$ and the general view appears to be that peptides need to be approximately $3.5 \mathrm{kDa}$ to contain sensitizing and eliciting allergenic capacity. This may be a realistic limit for some allergen-derived peptides. We have previously

Received: December 20, 2011

Revised: February 22, 2012

Accepted: February 24, 2012

Published: February 24, 2012 
shown that peptide fragments, as small as $2 \mathrm{kDa}$, have the capacity to sensitize and elicit allergic reactions. ${ }^{10}$ In the present study, we focus on examining under which conditions such peptide fragments retain their allergenic potential.

The objective of this study was to increase our knowledge and understanding of the allergenic capacity of small peptide fragments. This was done by using the known major peanut allergen Ara h 1 as a model allergen, based on the knowledge that this allergen retains its allergenic potential when digested to small peptide fragments while using pepsin as the enzyme for digestion. Digestion products of Ara $\mathrm{h} 1$ and fractions hereof were thoroughly characterized, and examination of sensitizing capacity was performed using a Brown Norway $(\mathrm{BN})$ rat model for food allergy.

\section{MATERIALS AND METHODS}

Purification of Peanut 7S Protein Ara h 1. Raw redskin peanuts (Julian Graves LTD, Kingswinford, United Kingdom) were skin peeled. Peanuts were frozen with liquid nitrogen and blended in a steel blender until a fine texture was obtained. Subsequently, the crushed peanuts were taken through two rounds of defatting [peanut:hexane, $1: 5, \mathrm{w}: \mathrm{v}, 1 \mathrm{~h}$, room temperature (RT)] and further homogenized in a coffee grinder.

Proteins were extracted in double-distilled water (peanut:water, 1:5, $\mathrm{w}: \mathrm{v})$ with $0.02 \%$ sodium azide (v:w), containing a protease inhibitor tablet (Roche complete mini protease inhibitor tablet, Roche, Sussex, United Kingdom) for $1 \mathrm{~h}$ at RT. After clarification by centrifugation (3000g, $20 \mathrm{~min}$ ) ammonium sulfate was added to a saturation of $70 \%$ and centrifuged $(30000 \mathrm{~g}, 30 \mathrm{~min})$. The supernatant was dialyzed against buffer (Tris $20 \mathrm{mM}, \mathrm{pH} 7.5,500 \mathrm{mM} \mathrm{NaCl}$ ) at $4{ }^{\circ} \mathrm{C}$, and samples of $40 \mathrm{~mL}$ were applied to a column of $10 \mathrm{~mL}$ of Con A Sepharose (GE Healthcare, Buckinghamshire, United Kingdom). Unbound protein was removed by washing with the buffer, while pure Ara $\mathrm{h} 1$ was eluted by addition of $400 \mathrm{mM}$ methyl $\alpha$-Dmannopyranoside. For further purity, eluted Ara h 1 was applied to a column of Superdex 200 prep grade (HiLoad 16/60 and 26/60 Superdex 200 prep grade, GE Healthcare) and eluted with $25 \mathrm{mM}$ Tris, $\mathrm{pH} 7$, and $150 \mathrm{mM} \mathrm{NaCl}$. Purified Ara h 1 was filtrated through a Millipore filter paper $(0.22 \mu \mathrm{m}$, Millipore Corp., Bedford, MA) with vacuum and afterward ultrafiltrated through an ultrafilter membrane (pore size, $10 \mathrm{kDa}$ ) with gas (argon, $10 \mathrm{psi}$ ). The Ara h 1 was dialyzed against $150 \mathrm{mM} \mathrm{NaCl}$, and the concentration was determined by UV absorbance reading at $280 \mathrm{~nm}$. Furthermore, concentration of purified Ara h 1 was determined by amino acid analysis to be $4.38 \mathrm{mg} / \mathrm{mL}$. The purified intact Ara $\mathrm{h} 1$ was analyzed for the presence of endotoxin by Lonza endotoxin testing service (Lonza, Verviers, Belgium).

$\mathrm{N}$-Terminal Sequencing of Intact Ara h 1. To analyze the isotype composition of intact Ara h 1 , amino terminal sequencing was performed. Protein sequencing of the intact Ara h $1(5 \mu \mathrm{L}, 16 \mathrm{pmol} / \mu \mathrm{L})$ was carried out by automated $\mathrm{N}$-terminal Edman degradation in a Procise 494 sequencer (Applied Biosystems, Foster City, CA) in liquid phase mode.

Simulated Gastric Digestion of Ara h 1. Gastric digestion was performed essentially as described by Bøgh et al. ${ }^{10}$ In short, pepsin immobilized to agarose (P0609, Sigma, St. Louis, MO) was washed two times $(100 \mathrm{~g}, 1 \mathrm{~min})$ in $10 \mathrm{~mL}$ of $1 \mathrm{mM} \mathrm{HCl}$. Purified Ara h 1 $(2.4 \mathrm{mg} / \mathrm{mL}$ in $150 \mathrm{mM} \mathrm{NaCl}$ ) was adjusted to $\mathrm{pH} 2.5$ with $1 \mathrm{M} \mathrm{HCl}$ and added to the immobilized pepsin to yield an activity of pepsin of approximately $170 \mathrm{U}$ per $\mathrm{mg}$ Ara $\mathrm{h} 1$. The solution was placed in a shaking incubator $\left(200 \mathrm{rpm}, 37{ }^{\circ} \mathrm{C}\right)$ for $120 \mathrm{~min}$. Reaction was stopped by adjusting the $\mathrm{pH}$ to 7 with $1 \mathrm{M} \mathrm{NaOH}$, centrifugation (1 $000 \mathrm{~g}, \mathrm{RT}, 2 \mathrm{~min})$, and filtration of supernatant through a $0.45 \mu \mathrm{m}$ Millipore filter followed by a $0.22 \mu \mathrm{m}$ filter.

Separation of Digested Ara $h 1$ into Fractions. For fractionation of the digested Ara $\mathrm{h}$ 1, preparative gel permeation chromatography (GPC) was performed. The digested Ara h $1(6 \mathrm{~mL}$, $2.3 \mathrm{mg} / \mathrm{mL}$ ) was loaded onto a Superdex 75 prep grade, HiLoad 26/60 column (GE Healthcare, Uppsala, Sweden) connected to GradiFrac system (Pharmacia Gradifrac FPLC system, GE Healthcare). Peptides were eluted at RT with $150 \mathrm{mM} \mathrm{NH}{ }_{4} \mathrm{HCO}_{3}, \mathrm{pH} 7.8$, at $1 \mathrm{~mL} / \mathrm{min}$ and collected in fractions of $4 \mathrm{~mL}$. The eluted peptides were detected by absorbances at 280 and $226 \mathrm{~nm}$. Four runs were made to fractionate all digested Ara h 1 . The column was calibrated for MW determination by applying a standard mixture consisting of $1 \mathrm{mg} / \mathrm{mL}$ ferritin $(440 \mathrm{kDa}$; F4503, Sigma), $0.75 \mathrm{mg} / \mathrm{mL}$ ovotransferrin (79 kDa; C-0880, Sigma), $1 \mathrm{mg} / \mathrm{mL}$ carbonic anhydrase (29 kDa; C-3934, Sigma), $1 \mathrm{mg} / \mathrm{mL}$ cytochrome C (14 kDa; C-2506, Sigma), $2 \mathrm{mg} / \mathrm{mL}$ apotinin $(6 \mathrm{kDa}$; A-1153, Sigma), and $0.1 \mathrm{mg} / \mathrm{mL}$ vitamin $\mathrm{B}_{12}(1.3 \mathrm{kDa}$; V-2876, Sigma).

Fractions from the four consecutive runs were collected and pooled according to the GPC profile (Figure 1) in three different pools

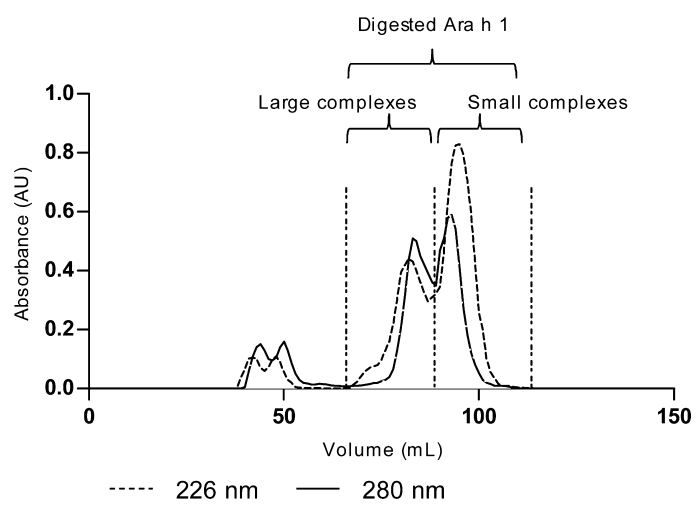

Figure 1. Preparative GPC of Ara h 1 digests. For fractionation of the Ara $\mathrm{h} 1$ digest, preparative GPC was performed in $150 \mathrm{mM}$ $\mathrm{HN}_{4} \mathrm{HCO}_{3}$, where Ara h 1 digest was separated into fractions based on the chromatographic profile. From the profile, shown with absorbances at 226 and $280 \mathrm{~nm}$, it was decided to make three different pools, indicated by the vertical dashed lines. The pools are referred to as: digested Ara h 1, large complexes and small complexes, where digested Ara h 1 is the whole pool of digest, consisting of both the fraction of large and the fraction of small complexes. The first double peak had an apparent MW of $60-440 \mathrm{kDa}$, indicating that some intact Ara $\mathrm{h} 1$ could be left in this fraction. To avoid the possible presence of any intact Ara h 1 in the digests, this double peak was excluded.

(in the following designated: digested Ara h 1, large complexes, and small complexes), where digested Ara h 1 constitute the fraction of large and small complexes. The pools were placed at $-80{ }^{\circ} \mathrm{C}$ for a minimum of $1 \mathrm{~h}$, afterward freeze-dried for approximately $48 \mathrm{~h}$, and rediluted in Milli $Q$ water [water drawn from a Milli $Q$ System equipped with an Organex cartridge from Millipore (Bedford, MA)] to give a concentration of approximately $1 \mathrm{mg} / \mathrm{mL}$.

Reverse Phase High-Performance Liquid Chromatography (RP-HPLC) Analysis. For analysis of purity and residual intact Ara h 1 in the digests, analytical RP-HPLC was performed. Samples $(40 \mu \mathrm{L}, 1$ $\mathrm{mg} / \mathrm{mL}$ ) were applied to a $\mu \mathrm{RPC} \mathrm{C} 2 / \mathrm{C} 18$ SC $2.1 / 10$ column (120 ̊ pore size, $3 \mu \mathrm{m}$ particle size, $100 \mathrm{~mm} \times 2.1 \mathrm{~mm}$ i.d., GE Healthcare) connected to a SMART system (GE Healthcare). Chromatography was performed at RT using $0.1 \%$ trifluoroacetic acid (TFA) in Milli Q water (v:v) as solvent A and 0.1\% TFA in Milli $Q$ water:acetonitrile $(\mathrm{ACN})(10: 90, \mathrm{v}: \mathrm{v})$ as solvent B. Elution was performed at a flow rate of $200 \mu \mathrm{L} / \mathrm{min}$ for $2.5 \mathrm{~min}$ with $5 \%$ solvent B, followed by elution with a linear gradient of increasing concentration of solvent B from 5 to $50 \%$ for $22 \mathrm{~min}$. Elution profiles were monitored using UV absorbance at 220 and $280 \mathrm{~nm}$. Fractions of $100 \mu \mathrm{L}$ were collected, dried in a vacuum centrifuge, and rediluted in $3 \mu \mathrm{L}$ of Milli $\mathrm{Q}$ water for analysis by matrix-assisted laser desorption/ionization time-of-flight (MALDITOF) mass spectrometry (MS).

Amino Acid Analysis. For examination of amino acid composition and quantification, amino acid analysis was performed according to Barkholt and Jensen ${ }^{32}$ after hydrolysis overnight in $\mathrm{HCl}$. 
A

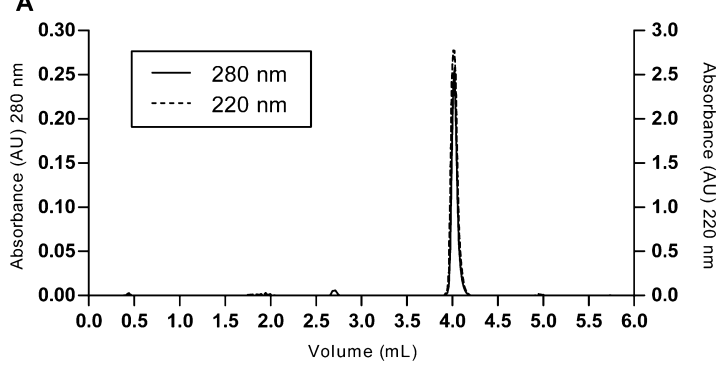

B

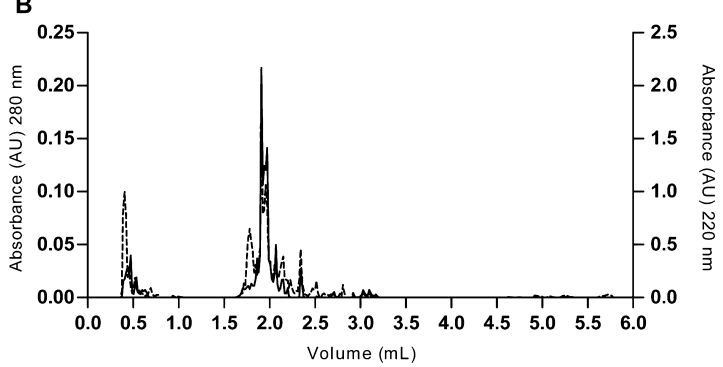

C

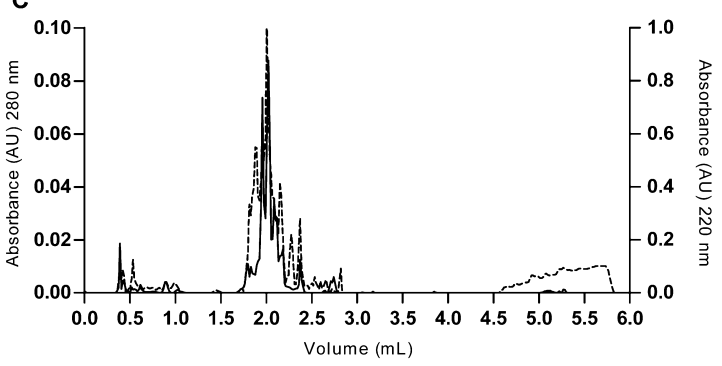

D

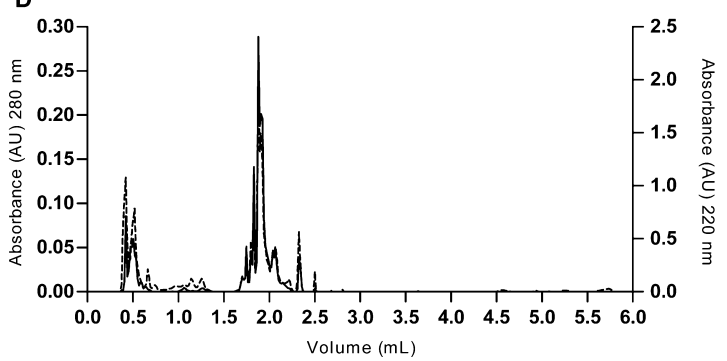

Figure 2. Analytical RP-HPLC. Comparison of chromatography profiles performed with $0.1 \%$ TFA/ACN for intact Ara h 1 (A), digested Ara h 1 (B), large complexes (C), and small complexes (D), shown with absorbances at 280 and $220 \mathrm{~nm}$.

MALDI-TOF MS. For analysis of peptide mass distribution in samples of Ara $\mathrm{h} 1$ digests, MALDI-TOF MS was performed on a Bruker MALDI-TOF MS (MALDI TOF/TOF, Ultraflex II, Bruker Daltonik GmbH, Bremen, Germany) equipped with pulsed ion extraction and $200 \mathrm{~Hz}$ Smart Beam laser. One microliter of the rediluted fractions from RP-HPLC was loaded onto a MALDI target, followed by addition of $1 \mu \mathrm{L}$ of $2 \%$ TFA and $1 \mu \mathrm{L}$ of $\alpha$-cyano-4hydrocinnamic acid $[5 \mu \mathrm{g} / \mu \mathrm{L}$ in $70 \%$ ACN (v:v), $0.1 \%$ TFA (v:v)]. All mass spectra were initially calibrated with a tryptic digest of $\beta$-lactoglobulin.

GPC Analysis. For analysis of aggregation profiles in samples of Ara h 1 digests, analytical GPC was performed. Samples $(40 \mu \mathrm{L}, 1 \mathrm{mg} / \mathrm{mL})$ were applied to a Superdex 75 PC 3.2/30 column (GE Healthcare) connected to a SMART system (GE Healthcare). Chromatography was performed at RT with a flow rate of $50 \mu \mathrm{L} / \mathrm{min}$ using $150 \mathrm{mM} \mathrm{HN} \mathrm{HCO}_{3}(\mathrm{pH} 7.8)$ as the eluent. The eluent profiles were monitored using UV absorbances at 220 and $280 \mathrm{~nm}$. The column was calibrated for MW using $12 \mu \mathrm{L}$ of the standard mixture previously described.

Animals. BN rats were from the in-house breeding colony at the National Food Institute (DTU, Denmark), weaned at 3 weeks of age and then housed in macrolon cages (two per cage) with a $12 \mathrm{~h}$ light:dark cycle, at $22 \pm 1{ }^{\circ} \mathrm{C}$ and $55 \pm 5 \%$ relative humidity. Rats were observed twice daily, and clinical signs were recorded.

Rats were kept on diet free from leguminous fruit for three generations to avoid tolerance against Ara h 1. Rat diet was produced in-house and based on rice flour, potato protein, and fish meal as protein sources, as previously described, ${ }^{10}$ with the exception of maize flakes being substituted with rice flour. Diet and acidified water were given ad libitum. Animal experiments were carried out at the National Food Institute (DTU, Denmark) facilities under conditions approved by the Danish Animal Experiments Inspectorate and the in-house Animal Welfare Committee.

Animal Sensitization Experiment. To study the sensitization capacity of intact Ara h 1, digested Ara h 1 and fractions of the digested Ara h 1, BN rats, 5-8 weeks of age, were allocated into five groups of 8-12 animals. Rats were immunized ip with PBS (control), $200 \mu \mathrm{g}$ of intact Ara h 1, $200 \mu \mathrm{g}$ of digested Ara h 1, or $200 \mu \mathrm{g}$ of either the large or the small complexes, with the use of Alhydrogel 2\% in PBS as adjuvant. Rats were immunized three times, at days 0, 14, and 28 , and sacrificed at day 35 by exsanguination using carbon dioxide inhalation as anesthesia. For further details, see Bøgh et al. ${ }^{10}$

Enzyme-Linked Immunosorbent Assays (ELISAs) for the Detection of Specific IgG1, IgG2a, and IgE. ELISAs were performed as previously described. ${ }^{10}$ Specific IgG1 and IgG2a were detected by direct binding of antibodies to plate-coated antigens, while $\operatorname{IgE}$ was detected in an antibody-capture ELISA, where Ara h 1 was coupled to digoxigenin.

Curve Calculations and Statistical Analysis. Curve calculations (XY analyses) and statistical calculations were made using GraphPad Prism version 5.00 (GraphPad Software, San Diego, CA). ELISA results expressed as antibody titers were examined for group differences, using the nonparametric one-way ANOVA, Kruskal-Wallis test, followed by Dunn's multiple comparison test for comparison of three or more groups. Differences between animal groups were regarded as significant when $P \leq 0.05$. Asterisks indicate a statistically significant difference between the given group and the control group. Asterisks over a horizontal line indicate a statistically significant difference between the two given groups: $*=P \leq 0.05$, ** $=P \leq 0.01$, and $* * *=$ $P \leq 0.001$

\section{RESULTS}

Characteristics of Purified Ara h 1. From N-terminal sequencing of the purified Ara $\mathrm{h}$ 1, it was evident that both known isoforms of Ara $\mathrm{h} 1$ were present, in the ratio of approximately 1:1 (data not shown). The sequences identified were RHPPGER and RSPPGER, demonstrating that the purified isoforms of Ara h 1 start at amino acid residue 79 (RHPPGER, Ara h 1, clone P17, SwissProt no. P43237) or 85 (RSPPGER, Ara h 1, clone P41B, SwissProt P43238), a confirmation of a study by Wichers et al., ${ }^{33}$ showing that Ara h 1 is expressed as a truncated protein, in which the first 78 and 84 amino acids, respectively, are cleaved off. The endotoxin analysis of the purified intact Ara $\mathrm{h} 1$ was $<2$ endotoxin units $(\mathrm{EU}) / \mathrm{mg}$ of Ara h 1. From RP-HPLC analysis (Figure 2A), Ara h 1 was calculated to be $>98 \%$ pure.

Characteristics of Digested Ara h 1 and Fractions Hereof. From RP-HPLC analyses, it was evident that no residual intact Ara h 1 was left in the three pools of Ara h 1 digests, since no detectable peak at the elution time for intact Ara $\mathrm{h} 1$ was seen in the chromatography profiles (Figure $2 \mathrm{~A}$ vs $\mathrm{B}-\mathrm{D})$. When comparing the RP-HPLC profiles for digested Ara h 1, large complexes and small complexes (Figure 2B-D), no significant differences are shown, indicating no apparent variation in peptide composition. However, when comparing 
A

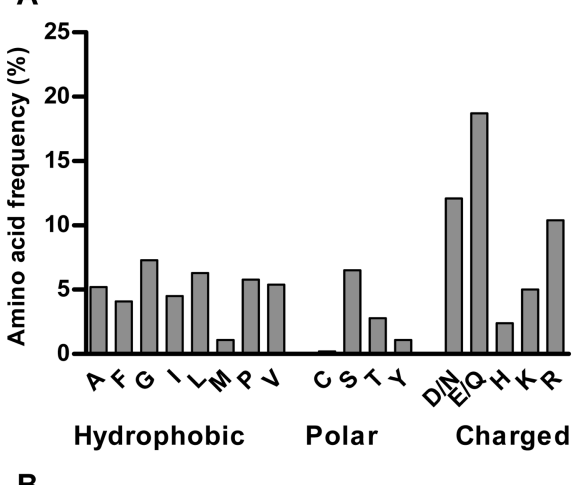

B

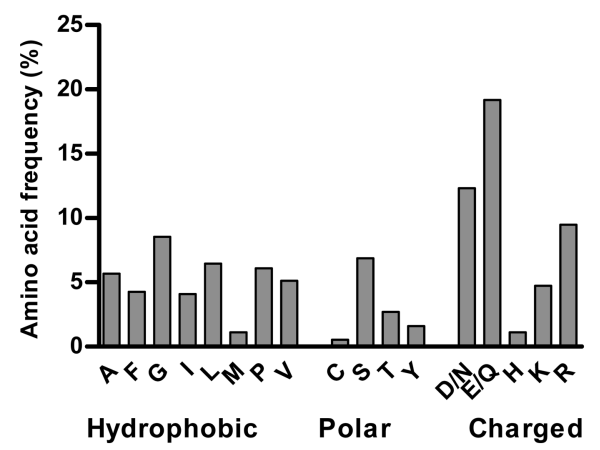

C

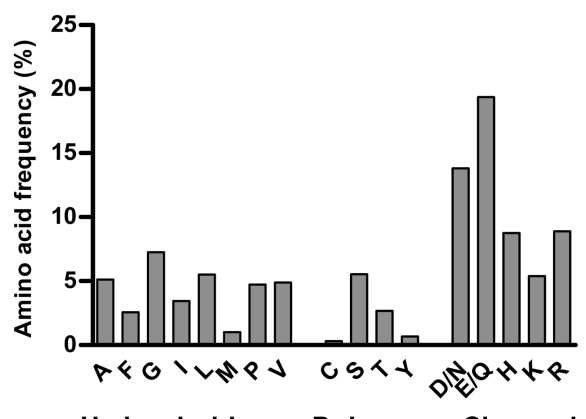

Hydrophobic Polar Charged

D

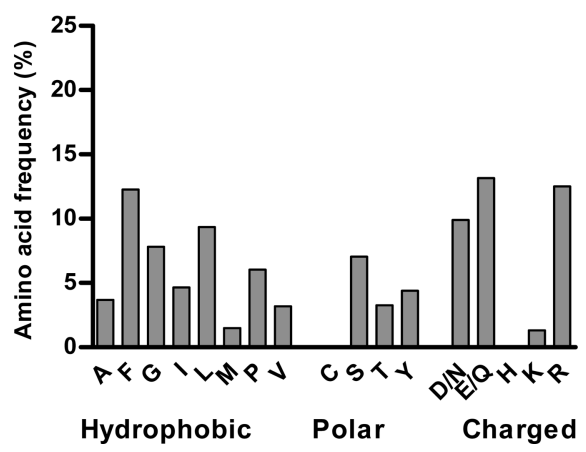

Figure 3. Amino acid frequency distribution. Comparison of the amino acid distribution for intact Ara h 1 (A), digested Ara h 1 (B), large complexes (C), and small complexes (D). The bars represent the frequency percentage of the indicated amino acid(s), represented by their one letter code, for either the intact Ara $\mathrm{h} 1$ or all peptides represented in the different pools of Ara $\mathrm{h} 1$ digests. Amino acids are grouped according to their physicochemical features.

the total amino acid distribution of the peptides present in the three different pools (Figure 3), it was revealed that differences did exist. While the amino acid distribution of digested Ara $\mathrm{h} 1$ represented the amino acid distribution for intact Ara $h$ 1, the large complexes and the small complexes were found to have an amino acid distribution different from that of the intact Ara $\mathrm{h} 1$. That digested Ara h 1 had an amino acid distribution similar to the distribution of intact Ara h 1 confirms that this pool contains a peptide composition representative of the intact Ara h 1, where hydrophobic amino acids are responsible for approximately $40 \%$, the polar for approximately $12 \%$, and the charged for approximately $48 \%$ of total amino acids. In contrast, the large complexes contain approximately 35\% hydrophobic amino acids, approximately $9 \%$ polar, and approximately $56 \%$ charged amino acids, while the small complexes contain approximately $48 \%$ hydrophobic amino acids, approximately $15 \%$ polar, and approximately $37 \%$ charged amino acids. This shows that peptides constituting the two fractions of digested Ara $\mathrm{h} 1$ are different from each other and thereby different from the whole pool of digested Ara h 1 and, therefore, do not contain peptides representing the intact Ara h 1 .

For examination of the peptide mass distribution profiles of the three different pools of Ara h 1 digests, MALDI-TOF MS was performed and demonstrated that Ara $\mathrm{h} 1$ was digested to small peptide fragments of sizes $\leq M_{r} 4000$ (Figure 4), of which more than $75 \%$ had apparent $M_{r}$ between 500 and 2000 . As in the whole pool of digested Ara h 1, the peptides in the large complexes had sizes up to $M_{r} 4000$, while in the small complexes, the peptides were $\leq M_{r} 3,000$. So while the digested Ara $\mathrm{h} 1$ and the fraction of large complexes contained peptides that were up to 33 amino acids, the longest peptides in the fraction of small complexes were up to 25 amino acids.
However, for all three pools of Ara h 1 digests, by far, most peptides were between 4 and 16 amino acids.

Realizing from the preparative GPC profile (Figure 1), based on which the fractions of Ara $\mathrm{h} 1$ digests were made that the peptides were in some kind of aggregated state, we analyzed in more detail the aggregation profiles of the three different pools. From the analytical GPC profiles shown in Figure 5, it is evident that the peptides in all three pools were indeed aggregated into complexes of larger sizes. However, from the profiles, it is revealed that the state of aggregation is very different for the three different pools. From the area under the $220 \mathrm{~nm}$ GPC absorbance curves, it was indicated that $25 \%$ of the peptides in digested Ara $\mathrm{h} 1$ were aggregated into complexes of up to $M_{r} 104000$, that $53 \%$ of the peptides in the large complexes were aggregated into complexes of up to $M_{r} 56$ 000 , and that $7 \%$ of the peptides in the small complexes were aggregated into complexes of up to $M_{r} 9000$. So, depending on the peptide composition profiles of the digested Ara h 1 and fractions hereof, the aggregation profiles differed significantly. See Table 1 for a summary of protein-chemical characteristics of the three different pools of Ara $\mathrm{h} 1$ digests.

Sensitizing Capacity of Digested Ara $h \quad 1$ and Fractions Hereof. Sera from individual BN rats dosed with either PBS (control), $200 \mu \mathrm{g}$ of intact Ara h 1, $200 \mu \mathrm{g}$ of digested Ara h 1, $200 \mu \mathrm{g}$ of large complexes, or $200 \mu \mathrm{g}$ of small complexes were evaluated for specific antibodies against both intact Ara h 1, digested Ara h 1, and fractions hereof. Looking at the antibody response, it was evident that while both intact Ara $\mathrm{h} 1$ and whole pool of digested Ara h 1 could induce specific IgG response, neither the large complexes nor the small complexes could induce specific IgG antibodies. Analyses of the specific IgG1 (Figure 6) and IgG2a, which revealed similar 

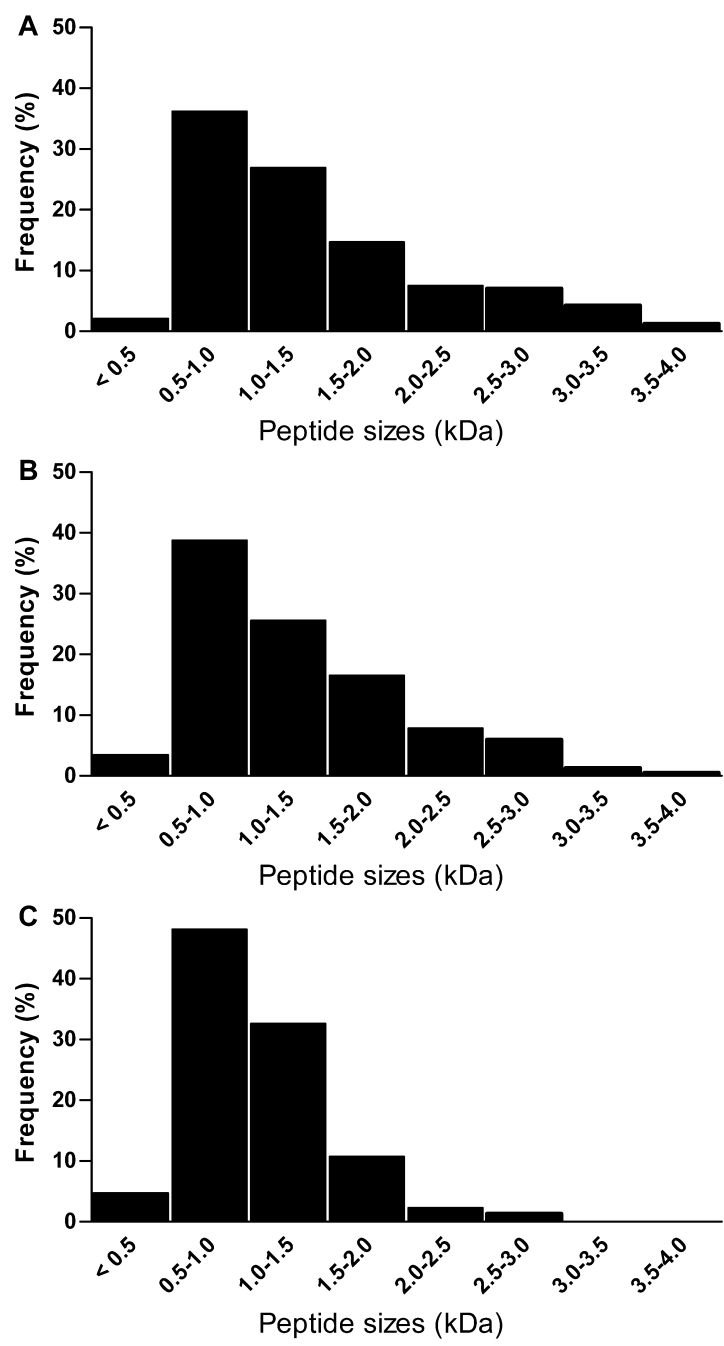

Figure 4. Peptide mass frequency distribution. Mass spectra of digested Ara h 1 (A), large complexes (B), and small complexes (C), shown in a histogram, where each bar corresponds to a peptide size interval of $0.5 \mathrm{kDa}$.

results (data not shown), showed that antibodies raised against intact Ara h 1 were able to recognize both intact Ara h 1 , digested Ara h 1, and both fractions of the digested Ara h 1, all to a statistically significant level. Although it is seen from Figure 6 that all animals immunized with intact Ara h 1 could react with all four samples of allergens, it is seen that the binding capacity was different (although not statistically significantly). IgG1 antibodies from the rats immunized with intact Ara h 1 had the highest binding capacity toward the intact Ara h 1, followed by the whole pool of digested Ara h 1 and then the fraction of large complexes. The lowest binding capacity was toward the fraction of small complexes. Contrary to antibodies raised against intact Ara h 1, the antibodies raised against the whole pool of digested Ara $h 1$ could only react with intact Ara h 1 and the whole pool of digested Ara h 1, the latter being the only one that was statistically significant. The specific antibody responses showed no statistically significant differences between rats immunized with intact and digested Ara $\mathrm{h} 1$.

From Figure 7, it is seen that both intact and digested Ara h 1 could induce specific IgE, although the intact Ara h 1-specific $\operatorname{IgE}$ response was only significant for antibodies raised against intact Ara h 1 . However, no statistically significant difference was seen between rats immunized with intact and digested
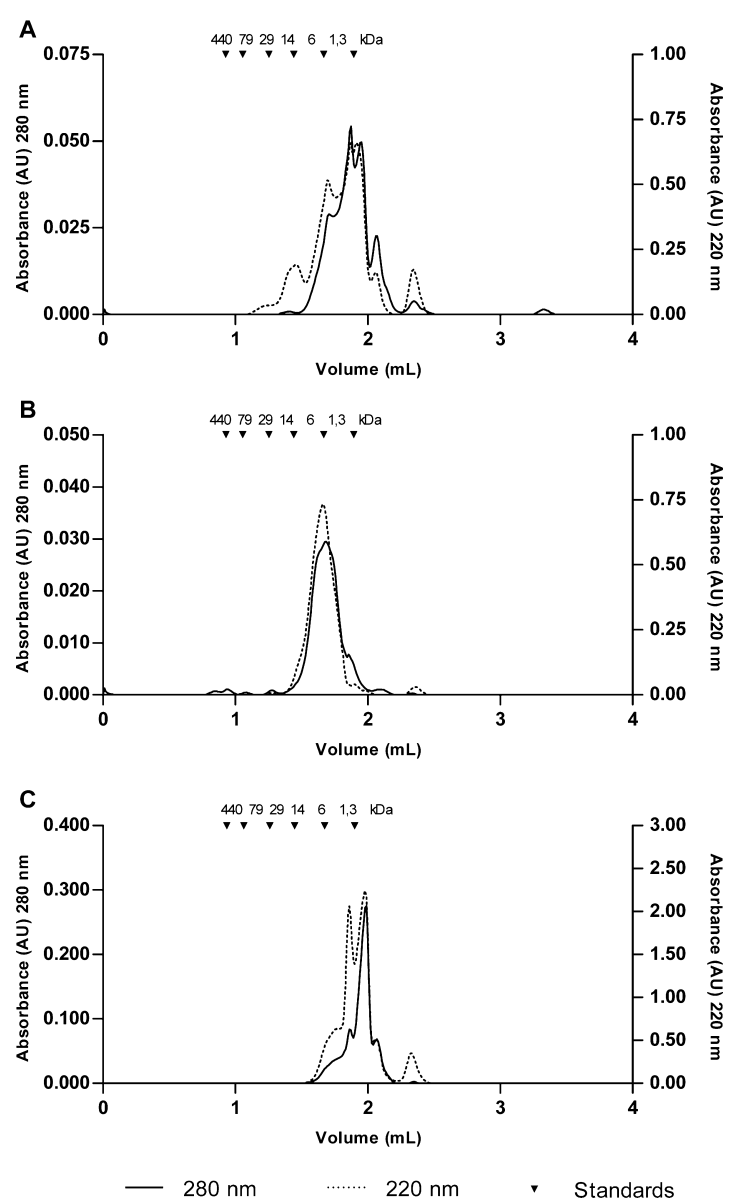

Figure 5. Analytical GPC. Comparison of chromatography profiles performed in $150 \mathrm{mM} \mathrm{NH}_{4} \mathrm{HCO}_{3}$ for digested Ara h 1 (A), fraction of large complexes (B), and fraction of small complexes (C), shown with absorbances at 280 and $220 \mathrm{~nm}$. Standard MW markers for absorbances at 280 and $220 \mathrm{~nm}$ are shown across the top of the graph.

Ara $\mathrm{h} 1$, respectively, by use of a multiple comparison test. Because it was not possible to couple the small peptide fragments in digested Ara $\mathrm{h} 1$ to a coupling protein, which could be detected by commercially available secondary antibodies, we could not determine digested Ara h 1-specific $\mathrm{IgE}$ responses. We anticipate, however, that the specific $\operatorname{IgE}$ response of rats immunized with digested Ara $h 1$ would be higher for digested Ara h 1 than the one shown for intact Ara h 1 . These speculations are based on our knowledge that specific IgE follows the specific IgG1 and IgG2a. ${ }^{10,34}$

\section{DISCUSSION}

The present study confirms that Ara h 1 retains both the sensitizing and the reacting potential, when digested to small peptide fragments. This signifies that digestion of Ara $h 1$ is not an effective approach for significant reduction of neither sensitizing nor IgE binding capacity and manifest that a correlation between resistance to digestion and allergenicity is not a general parameter. While Ara $\mathrm{h} 1$ does not need to survive the digestion process as an intact protein or as large fragments to react with the immune system for induction of a specific immune response, this could still be the case for other food allergens. Previous studies examining the influence of digestion on the allergenic potential of other 
Table 1. Overview of Protein-Chemical Characteristics of the Different Pools of Ara h 1 Digests

\begin{tabular}{|c|c|c|c|c|c|c|}
\hline \multirow[b]{2}{*}{ pool of digested Ara h 1} & \multicolumn{3}{|c|}{ amino acid distribution (\%) } & \multirow[b]{2}{*}{ peptide sizes $\left(M_{r}\right)$} & \multicolumn{2}{|c|}{ aggregation profile } \\
\hline & hydrophobic & polar & charged & & amount (\%) & sizes $\left(M_{r}\right)$ \\
\hline digested Ara h 1 & 40 & 12 & 48 & $\leq 4$ & 25 & 104000 \\
\hline fraction of large complexes & 35 & 9 & 56 & $\leq 4$ & 53 & 56000 \\
\hline Fraction of small complexes & 48 & 15 & 37 & $\leq 3$ & 7 & 9000 \\
\hline
\end{tabular}

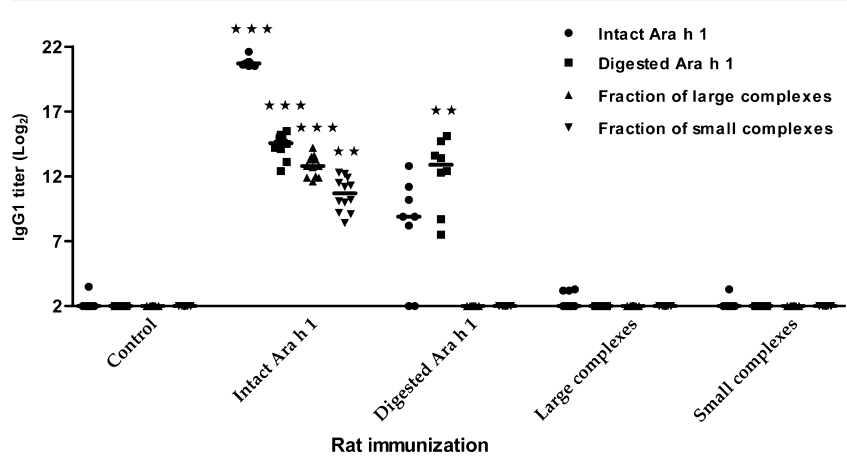

Figure 6. Specific IgG1 response. Comparison of specific IgG1 titer values, for groups of rats immunized with either PBS (control), intact Ara h 1, digested Ara h 1, large complexes, or small complexes. In each group of rats, IgG1 antibodies were examined for their binding to both intact Ara h 1, digested Ara h 1, the fraction of large complexes, and the fraction of small complexes. Each symbol represents an individual rat. Horizontal bars indicate the median value for each group of rats. The statistically significant difference between the groups was determined using Kruskal-Wallis test followed by Dunn's multiple comparison test. Asterisks indicate statistically significant difference of the given allergen-dosed group as compared with the control group for the given specificity (represented by identical symbols).

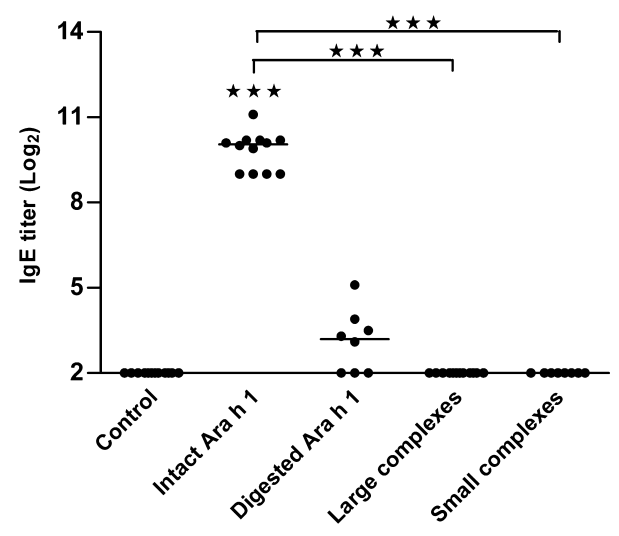

Rat immunization

Figure 7. Specific IgE response against intact Ara h 1. Comparison of Ara $\mathrm{h}$ 1-specific IgE titer values, for groups of rats, immunized with either PBS (control), intact Ara h 1, digested Ara h 1, large complexes, or small complexes. Each symbol represents the specific IgE titer response toward intact Ara h 1 for an individual rat. Horizontal bars indicate median values. Statistically significant differences between groups of rats were determined using Kruskal-Wallis test followed by Dunn's multiple comparison test. Asterisks indicate statistically significant difference of the given allergen-dosed group as compared with the control group, and asterisks over a horizontal line indicate a statistically significant difference between the two given allergen-dosed groups.

food proteins have revealed digestion to be an effective approach for a significant impairment of sensitization ${ }^{35,36}$ and IgE-binding capacity. ${ }^{35,37,38}$
We have previously shown that mixtures of peptides smaller than $2-5 \mathrm{kDa}$, which was generally thought to be the lower size limit for a peptide with inherent sensitizing capacity, ${ }^{31}$ may still act as a "complete" allergen, ${ }^{39}$ being able to sensitize, elicit allergic reaction, and react with IgE. The aim of this study was to further examine how small peptides retain their sensitizing capacity. This was done by studying the specific antibody responses in BN rats immunized with digested Ara $\mathrm{h} 1$ and fractions hereof, separated on the basis of the aggregation profile of the peptides.

From the GPC analysis of the digested Ara h 1, it was evident that peptides did aggregate into complexes of larger sizes. This may be a result of noncovalent interactions, like hydrophobic interactions, since the single cysteine residue present in the Ara h 1 molecule cannot account for the amount and sizes of the complexes. That the sensitizing capacity of digested Ara $\mathrm{h} 1$ is a result of the peptide fragments forming aggregates was hypothesized in earlier studies. 9,10 That aggregation may enhance the immune response toward antigen subunits was already recognized in 1978, where Morein et al. ${ }^{40}$ showed that aggregation of subunits by hydrophobic interactions induced a significant higher immune response as compared to free subunits, suggesting an importance of multimeric structures. The same has been shown with the allergen melittin, a bee venom protein of $2.8 \mathrm{kDa}$ ( 26 amino acids), with one B cell epitope $^{41}$ and one $\mathrm{T}$ cell epitope. ${ }^{42}$ Melittin was able to induce specific IgG and IgE responses in humans and animals. The immunogenicity and allergenicity of the melittin were found to correlate with oligomerization of the molecules. ${ }^{43-45}$ Also, the state of aggregation may influence the way in which proteins are presented to the immune system in the gastrointestinal tract. This was indicated in a study by Roth-Walter et al., ${ }^{46}$ which showed that aggregation of proteins from milk inhibited their uptake by intestinal epithelial cells and redirected uptake to Peyer's patches, promoting a significantly higher Th2associated antibody response. This supports the theory that aggregation is a plausible explanation for the allergenic potential of digested Ara h 1.

It is well recognized that small peptides in general are poor immunogens and that peptides in general need to be of a certain size to behave as sensitizing allergens. Muller ${ }^{31}$ stated that it is commonly assumed that peptides in the range of 2-5 $\mathrm{kDa}$ behave like haptens and are not immunogenic. It is known that for a protein to induce an allergic response, it requires the presence of both $\mathrm{T}$ and $\mathrm{B}$ cell epitopes. However, immunization with free peptides as small as 6-14 amino acid residues long has been reported to induce acceptable antibody responses. ${ }^{31,47,48}$ This is in concordance with the earlier study of sensitizing capacity of digested Ara h 1, where peptides of less than $2 \mathrm{kDa}$ were able to induce a statistically significant antibody response without the use of additional adjuvant. ${ }^{10}$ This may indicate that the sensitizing capacity of digested Ara h 1 could also be an intrinsic feature of the free peptides themselves. It has been shown several times that induction of antibodies does not require covalent linkage between the 
peptide behaving as $\mathrm{T}$ cell epitope and the peptide behaving as $B$ cell epitope. ${ }^{49-52}$ It has also been shown that amino acid sequences that did not function as an antibody epitope when part of a larger peptide were able to function as an antibody epitope when presented as free small peptides in mixtures with other peptides. ${ }^{47,49}$ This is consistent with the present study showing that antibodies raised in rats immunized with the whole pool of digested Ara h 1 had higher binding capacity toward the digested Ara h 1 than toward the intact, indicating that new epitopes that were not accessible in the intact Ara $h 1$ became accessible when digested to small peptides. These results indicate that poor immunogenicity of peptides can be overcome by coimmunization with mixtures of the peptides.

To further elucidate why digested Ara $h 1$ retained the sensitizing potential, $\mathrm{BN}$ rats were immunized with fractions of the digest. Strikingly, this study showed that by separating the peptides of digested Ara h 1 into two fractions, the sensitizing capacity was lost. While only a small part of the peptides in the fraction of small complexes did aggregate, more than half of the peptides in the fraction of large complexes were in aggregates of sizes up to $M_{r} 56000$. This is a larger part than in the whole pool of digested Ara h 1 where only $25 \%$ of the peptides aggregated. This reveals that allergenicity of the digested Ara $h$ 1 is not simply a result of the peptides aggregating. The given fact that aggregated complexes in the digested Ara $\mathrm{h} 1$ was up to $M_{r} 104000$, nearly twice the size of the largest aggregates in the large complexes, indicates that the aggregation profile changed by means of fractionation in GPC. Instead of the sensitizing capacity being simply a result of aggregation of the peptides, the present study indicates that sensitization depends on the way the peptides do aggregate. A possible explanation may be that the aggregated peptides in the digested Ara $\mathrm{h} 1$ are in an architecture representing the natural configuration of intact Ara h 1, while the peptides in the large complexes are in a state of de novo aggregation. Epitopes have been classified as either linear or conformational, ${ }^{53,54}$ and it is believed that most $\mathrm{B}$ cell epitopes are conformational. ${ }^{39,55,56}$ However, for food allergens, it has been suggested that linear epitopes could be of importance, since the protein is presented to the mucosal immune system of the gastrointestinal tract as denatured and digested protein fragments, favoring a B cell response toward linear sequences of amino acids. ${ }^{57,58}$ Indeed, linear IgE-binding epitopes have been identified for various food allergens. ${ }^{58}$ Nevertheless, linear IgE-binding epitopes have been found to contribute only a little to the total IgE binding, ${ }^{53,54,56,59}$ and no biochemical characteristics were found to be shared between the linear IgE-binding epitopes. ${ }^{58}$

If sensitizing potential of digested Ara $h 1$ is an intrinsic feature of the free peptides themselves, however, coimmunization with $B$ and $T$ cell epitopes does not explain why the digested Ara h 1 retained sensitizing capacity, while this sensitizing capacity was abolished when the peptides were separated into fractions. An explanation could be that the stability of digested Ara h 1 by some means was changed when the peptides were separated. From amino acid analysis, it is evident that when the peptides of digested Ara $h 1$ were separated by GPC, the amino acid distribution was significantly changed, leaving most charged peptides in the fraction of large complexes and most hydrophobic peptides in the fraction of small complexes. Consequently, the same peptides may possibly not be present in the two different fractions and certainly not to the same extent. That the type and amount of peptides are of importance has been shown in several studies of peptide vaccine development. Mixtures of peptides have been shown to induce more B cell epitopes than did the very same peptides when fused or administered alone, ${ }^{47,49,51,60}$ indicating that peptides may function as adjuvant or in a synergistic way. Accordingly, the present study suggests that most peptides in the digest need to be present to serve as adjuvant augmenting the immune response against other peptides and therefore need to be administered together. In addition, it has been demonstrated that peptides representing different $\mathrm{T}$ cell epitopes varied significantly in their ability to provide help to $\mathrm{B}$ cells. This suggests that the inherent property of the peptides constituting $\mathrm{T}$ cell epitope peptides differ in efficacy and that this feature may be independent of the protein from where they origin. $^{51,52}$

The present study revealed that different requirements are needed for a protein to retain sensitizing and antibody binding capacity. While the fractions of digested Ara $h 1$ had no sensitizing potential, both fractions retained reactivity with antibodies raised in rats immunized with intact Ara $\mathrm{h} 1$. This shows that there are larger requirements for peptides to sensitize than for the peptides to retain reacting activity. These results seem reasonable, since reacting activity only needs an amino acid sequence resembling an antibody epitope, while sensitizing capacity requires the ability to be recognized by the immune system de novo, priming of specific B cells as well as activation of $\mathrm{T}$ cells, providing the additional help needed for proper differentiation and proliferation of antibody secreting plasma cells. If most $B$ cell epitopes of Ara $h 1$ are conformational, this leaves us to explain how antibodies directed against intact Ara h 1 are able to react with peptides from the small complexes. Peptides in the small complexes do not aggregate to an extent where they could represent conformational epitopes but must instead be epitopes derived from the linear sequence of the allergen. Aalberse ${ }^{39}$ states that the main factor is the huge difference in binding affinity between antibodies interacting with intact protein versus interacting with peptides from the very same protein. This means that the peptides are much less efficient as compared to the intact protein for antibody binding. The peptide may for instance represent only a fraction of the epitope ${ }^{39,54}$ or may only be a mimic of the epitope for which the antibody was originally directed against, ${ }^{53}$ with only a certain degree of resemblance. The strength of interaction with the peptide could be decreased even more because of the higher flexibility of free peptides as compared to the complete protein. ${ }^{39}$ This is in agreement with our own unpublished data, demonstrating a higher avidity between the binding of antibodies and intact protein as compared to the binding of the antibodies and digests. It is suggested that about $10 \%$ of antibodies directed toward conformational epitopes are able to react with linear peptide fragments of the protein, ${ }^{53,54,56}$ which correlates well with the present study.

In summary, the current study showed that while digested Ara $\mathrm{h} 1$ has sensitizing capacity, this capacity was lost after separation of the peptides in the digest into fractions. The sensitizing capacity of the digest was not dependent on single peptides but rather the sum of peptides. However, to unravel if the sensitizing capacity is a result of mixtures of free peptides or is a result of the peptides being in a defined aggregated state, further studies are needed. On the basis of the present study, we may conclude that the way in which the digests are presented to the immune systems is of significant importance 
for the outcome and confirms the complexity of the mechanisms involved in sensitization.

\section{AUTHOR INFORMATION}

\section{Corresponding Author}

*Tel: +45 35887092. Fax: +45 35887001. E-mail: kalb@food. dtu.dk.

\section{Present Address}

"University of Manchester, Manchester Interdisciplinary Biocentre, Manchester Academic Health Science Centre, School of Translational Medicine, 131 Princess Street, Manchester M1 7DN, United Kingdom.

\section{Funding}

We gratefully acknowledge financial support from the FOOD Denmark Research School, the Danish Dairy Board, and the Technical University of Denmark.

Notes

The authors declare no competing financial interest.

\section{ACKNOWLEDGMENTS}

We thank Nehad Moradian, Anne Blicher, Anne Ørngreen, Eva Ferdinansen, Elise Navntoft, Eigil Frank, Sarah Simonsen, Maja Danielsen, and Kenneth Worm for their excellent assistance in laboratory and animal facilities.

\section{ABBREVIATIONS USED}

ACN, acetonitrile; BN, Brown Norway; EU, endotoxin unit; GPC, gel permeation chromatography; MALDI-TOF, matrixassisted laser desorption/ionization time-of-flight; MS, mass spectrometry; MW, molecular weight; RP-HPLC, reverse phase high-performance liquid chromatography; SGF, simulated gastric fluid; TFA, trifluoroacetic acid

\section{REFERENCES}

(1) Taylor, S. L.; Hefle, S. L. Will genetically modified foods be allergenic? J. Allergy Clin. Immunol. 2001, 107 (5), 765-771.

(2) Mills, E. N.; Jenkins, J. A.; Alcocer, M. J.; Shewry, P. R. Structural, biological, and evolutionary relationships of plant food allergens sensitizing via the gastrointestinal tract. Crit Rev. Food Sci. Nutr. 2004, 44 (5), 379-407.

(3) Astwood, J. D.; Leach, J. N.; Fuchs, R. L. Stability of food allergens to digestion in vitro. Nat. Biotechnol. 1996, 14 (10), 12691273 .

(4) Thomas, K.; Aalbers, M.; Bannon, G. A.; Bartels, M.; Dearman, R. J.; Esdaile, D. J.; Fu, T. J.; Glatt, C. M.; Hadfield, N.; Hatzos, C.; Hefle, S. L.; Heylings, J. R.; Goodman, R. E.; Henry, B.; Herouet, C.; Holsapple, M.; Ladics, G. S.; Landry, T. D.; MacIntosh, S. C.; Rice, E. A.; Privalle, L. S.; Steiner, H. Y.; Teshima, R.; van, R. R.; Woolhiser, M.; Zawodny, J. A multi-laboratory evaluation of a common in vitro pepsin digestion assay protocol used in assessing the safety of novel proteins. Regul. Toxicol. Pharmacol. 2004, 39 (2), 87-98.

(5) Fu, T. J.; Abbott, U. R.; Hatzos, C. Digestibility of food allergens and nonallergenic proteins in simulated gastric fluid and simulated intestinal fluid-A comparative study. J. Agric. Food Chem. 2002, 50 (24), 7154-7160.

(6) Kenna, J. G.; Evens, R. M. Digestibility of proteins in simulated gastric fluid [Abstract]. Toxicologist 2000, 54, 141.

(7) Dupont, D.; Mandalari, G.; Molle, D.; Jardin, J.; Leonil, J.; Faulks, R. M.; Wickham, M. S.; Mills, E. N.; Mackie, A. R. Comparative resistance of food proteins to adult and infant in vitro digestion models. Mol. Nutr. Food Res. 2010, 54 (6), 767-780.

(8) Moreno, F. J. Gastrointestinal digestion of food allergens: effect on their allergenicity. Biomed. Pharmacother. 2007, 61 (1), 50-60.
(9) Eiwegger, T.; Rigby, N. M.; Mondoulet, L.; Bernard, H.; Krauth, M. T.; Boehm, A.; Dehlink, E.; Valent, P.; Wal, J. M.; Mills, E. N. C.; Szépfalusi, Z. Gastro-duodenal digestion products of the major peanut allergen Ara h 1 retain an allergenic potential. Clin. Exp. Allergy 2006, 36 (10), 1281-1288.

(10) Bøgh, K. L.; Kroghsbo, S.; Dahl, L.; Rigby, N. M.; Barkholt, V.; Mills, E. N.; Madsen, C. B. Digested Ara h 1 has sensitizing capacity in Brown Norway rats. Clin. Exp. Allergy 2009, 39 (10), 1611-1621.

(11) FAO/WHO. Evaluation of Allergenicity of Genetically Modified Foods. Report of a Joint FAO/WHO Expert Consulation on Allergenicity of Food Derived from Biotechnology, 22-25 January 2001; Food and Agriculture Organisation of the United Nations (FAO): Rome, Italy, 2001.

(12) Codex Alimentarius Commission. Alinorm 03/34: Joint FAO/ WHO Food Standard Programme, Codex Alimentarius Commission, Twenty-Fifth Session, Rome, Italy 30 June-5 July, 2003; 03.

(13) EFSA Panel on Genetically Modified Organisms (GMO).. Draft Scientific Opinion on the assessment of allergenicity of GM plants and microorganisms and derived food and feed. EFSA J. 2010, 8 (7), $1-168$.

(14) Mandalari, G.; del-Patient, K.; Barkholt, V.; Baro, C.; Bennett, L.; Bublin, M.; Gaier, S.; Graser, G.; Ladics, G. S.; Mierzejewska, D.; Vassilopoulou, E.; Vissers, Y. M.; Zuidmeer, L.; Rigby, N. M.; Salt, L. J.; Defernez, M.; Mulholland, F.; Mackie, A. R.; Wickham, M. S.; Mills, E. N. In vitro digestibility of beta-casein and beta-lactoglobulin under simulated human gastric and duodenal conditions: a multi-laboratory evaluation. Regul. Toxicol. Pharmacol. 2009, 55 (3), 372-381.

(15) Morisawa, Y.; Kitamura, A.; Ujihara, T.; Zushi, N.; Kuzume, K.; Shimanouchi, Y.; Tamura, S.; Wakiguchi, H.; Saito, H.; Matsumoto, K. Effect of heat treatment and enzymatic digestion on the B cell epitopes of cow's milk proteins. Clin. Exp. Allergy 2009, 39 (6), 918-925.

(16) Hourihane, J. O. Peanut allergy. Pediatr. Clin. North Am. 2011, 58 (2), 445-458.

(17) Sicherer, S. H.; Furlong, T. J.; Munoz-Furlong, A.; Burks, A. W.; Sampson, H. A. A voluntary registry for peanut and tree nut allergy: Characteristics of the first 5149 registrants. J. Allergy Clin. Immunol. 2001, 108, 128-132.

(18) Grundy, J.; Matthews, S.; Bateman, B.; Dean, T.; Arshad, S. H. Rising prevalence of allergy to peanut in children: Data from 2 sequential cohorts. J. Allergy Clin. Immunol. 2002, 110 (5), 784-789.

(19) Sicherer, S. H.; Munoz-Furlong, A.; Godbold, J. H.; Sampson, H. A. US prevalence of self-reported peanut, tree nut, and sesame allergy: 11-year follow-up. J. Allergy Clin. Immunol. 2010, 125 (6), $1322-1326$.

(20) Burks, A. W.; Williams, L. W.; Helm, R. M.; Connaughton, C.; Cockrell, G.; O'Brien, T. Identification of a major peanut allergen, Ara $\mathrm{h} \mathrm{I}$, in patients with atopic dermatitis and positive peanut challenges. J. Allergy Clin. Immunol. 1991, 88 (2), 172-179.

(21) Burks, A. W.; Shin, D.; Cockrell, G.; Stanley, J. S.; Helm, R. M.; Bannon, G. A. Mapping and mutational analysis of the IgE-binding epitopes on Ara h 1, a legume vicilin protein and a major allergen in peanut hypersensitivity. Eur. J. Biochem. 1997, 245 (2), 334-339.

(22) Burks, A. W.; Cockrell, G.; Stanley, J. S.; Helm, R. M.; Bannon, G. A. Recombinant peanut allergen Ara h I expression and IgE binding in patients with peanut hypersensitivity. J. Clin. Invest. 1995, 96 (4), $1715-1721$.

(23) Maleki, S. J.; Kopper, R. A.; Shin, D. S.; Park, C. W.; Compadre, C. M.; Sampson, H.; Burks, A. W.; Bannon, G. A. Structure of the major peanut allergen Ara $\mathrm{h} 1$ may protect IgE-binding epitopes from degradation. J. Immunol. 2000, 164 (11), 5844-5849.

(24) Shin, D. S.; Compadre, C. M.; Maleki, S. J.; Kopper, R. A.; Sampson, H.; Huang, S. K.; Burks, A. W.; Bannon, G. A. Biochemical and structural analysis of the $\mathrm{IgE}$ binding sites on ara $\mathrm{h} 1$, an abundant and highly allergenic peanut protein. J. Biol. Chem. 1998, 273 (22), 13753-13759.

(25) Ditto, A. M.; Neilsen, C. V.; Neerukonda, S.; Shreffler, W. G.; Bryce, P. J. Clinical reactivity to raw peanut correlates with $\operatorname{IgE}$ binding to conformational epitopes of Ara h 1: A case report. Allergy. 2010, 65 (11), 1485-1486. 
(26) van Boxtel, E. L.; Koppelman, S. J.; van den Broek, L. A.; Gruppen, H. Determination of pepsin-susceptible and pepsin-resistant epitopes in native and heat-treated peanut allergen Ara h 1. J. Agric. Food Chem. 2008, 56 (6), 2223-2230.

(27) Lack, G.; Chapman, M.; Kalsheker, N.; King, V.; Robinson, C.; Venables, K. Report on the potential allergenicity of genetically modified organisms and their products. Clin. Exp. Allergy 2002, 32 (8), $1131-1143$

(28) Poulsen, O. M.; Hau, J. Murine Passive Cutaneous Anaphylaxis Test (Pca) for the All Or None Determination of Allergenicity of Bovine Whey Proteins and Peptides. Clin. Allergy 1987, 17 (1), 75-83.

(29) Van Beresteijn, E. C. H.; Peeters, R. A.; Kaper, J.; Meijer, R. J. G. M.; Robben, A. J. P. M; Schmidt, D. G. Molecular-Mass Distribution, Immunological Properties and Nutritive-Value of Whey-Protein Hydrolysates. J. Food Prot. 1994, 57 (7), 619-625.

(30) Huby, R. D. J.; Dearman, R. J.; Kimber, I. Why are some proteins allergens? Toxicol. Sci. 2000, 55 (2), 235-246.

(31) Muller, S. Immunization with peptides. Lab. Tech. Biochem. Mol. Biol. 1999, 133-177.

(32) Barkholt, V.; Jensen, A. L. Amino acid analysis: Determination of cysteine plus half-cystine in proteins after hydrochloric acid hydrolysis with a disulfide compound as additive. Anal. Biochem. 1989, 177 (2), 318-322.

(33) Wichers, H. J.; De, B. T.; Savelkoul, H. F.; Van, A. A. The major peanut allergen Ara $\mathrm{h} 1$ and its cleaved-off $\mathrm{N}$-terminal peptide; possible implications for peanut allergen detection. J. Agric. Food Chem. 2004, 52 (15), 4903-4907.

(34) Kroghsbo, S.; Bøgh, K. L.; Rigby, N. M.; Mills, E. N.; Rogers, A.; Madsen, C. B. Sensitization with 7 S globulins from peanut, hazelnut, soy or pea induces $\operatorname{IgE}$ with different biological activities which are modified by soy tolerance. Int. Arch. Allergy Immunol. 2011, 155 (3), 212-224.

(35) Untersmayr, E.; Scholl, I.; Swoboda, I.; Beil, W. J.; ForsterWaldl, E.; Walter, F.; Riemer, A.; Kraml, G.; Kinaciyan, T.; Spitzauer, S.; Boltz-Nitulescu, G.; Scheiner, O.; Jensen-Jarolim, E. Antacid medication inhibits digestion of dietary proteins and causes food allergy: A fish allergy model in Balb/c mice. J. Allergy Clin. Immunol. 2003, 112 (3), 616-623.

(36) Scholl, I.; Untersmayr, E.; Bakos, N.; Roth-Walter, F.; Gleiss, A.; Boltz-Nitulescu, G.; Scheiner, O.; Jensen-Jarolim, E. Antiulcer drugs promote oral sensitization and hypersensitivity to hazelnut allergens in BALB/c mice and humans. Am. J. Clin. Nutr. 2005, 81 (1), 154-160.

(37) Untersmayr, E.; Poulsen, L. K.; Platzer, M. H.; Pedersen, M. H.; Boltz-Nitulescu, G.; Skov, P. S.; Jensen-Jarolim, E. The effects of gastric digestion on codfish allergenicity. J. Allergy Clin. Immunol. 2005, 115 (2), 377-382.

(38) Schimek, E. M.; Zwolfer, B.; Briza, P.; Jahn-Schmid, B.; Vogel, L.; Vieths, S.; Ebner, C.; Bohle, B. Gastrointestinal digestion of Bet v 1-homologous food allergens destroys their mediator-releasing, but not T cell-activating, capacity. J. Allergy Clin. Immunol. 2005, 116 (6), 1327-1333.

(39) Aalberse, R. C. Structural biology of allergens. J. Allergy Clin. Immunol. 2000, 106 (2), 228-238.

(40) Morein, B.; Helenius, A.; Simons, K.; Pettersson, R.; Kaariainen, L.; Schirrmacher, V. Effective subunit vaccines against an enveloped animal virus. Nature 1978, 276 (5689), 715-718.

(41) King, T. P.; Kochoumian, L.; Joslyn, A. Melittin-specific monoclonal and polyclonal $\operatorname{IgE}$ and IgG1 antibodies from mice. J. Immunol. 1984, 133 (5), 2668-2673.

(42) Fehlner, P. F.; Berg, R. H.; Tam, J. P.; King, T. P. Murine T cell responses to melittin and its analogs. J. Immunol. 1991, 146 (3), 799806.

(43) King, T. P.; Wade, D.; Coscia, M. R.; Mitchell, S.; Kochoumian, L.; Merrifield, B. Structure-immunogenicity relationship of melittin, its transposed analogues, and D-melittin. J. Immunol. 1994, 153 (3), $1124-1131$.

(44) King, T. P.; Coscia, M. R.; Kochoumian, L. Structureimmunogenicity relationship of a peptide allergen, melittin. In
Molecular Biology and Immunology of Allergens; Kraft, D., Sehon, A., Eds.; CRC Press: Ann. Arbor, 1993; Vol. 11, pp 11-19.

(45) King, T. P.; Coscia, M. R.; Kochoumian, L. Structureimmunogenicity relationship of melittin and its $\mathrm{N}$-terminal truncated analogs. Biochemistry 1993, 32 (13), 3506-3510.

(46) Roth-Walter, F.; Berin, M. C.; Arnaboldi, P.; Escalante, C. R.; Dahan, S.; Rauch, J.; Jensen-Jarolim, E.; Mayer, L. Pasteurization of milk proteins promotes allergic sensitization by enhancing uptake through Peyer's patches. Allergy 2008, 63 (7), 882-890.

(47) Atassi, M. Z.; Young, C. R. Discovery and implications of the immunogenicity of free small synthetic peptides: Powerful tools for manipulating the immune system and for production of antibodies and $\mathrm{T}$ cells of preselected submolecular specificities. Crit. Rev. Immunol. 1985, 5 (4), 387-409.

(48) Antoni, G.; Mariani, M.; Presentini, R.; Lafata, M.; Neri, P.; Bracci, L.; Cianfriglia, M. Production and characterization of monoclonal antibodies to anti-human chorionic somatomammotropin by immunization with two free synthetic peptides. Mol. Immunol. 1985, 22 (11), 1237-1241.

(49) Sarobe, P.; Lasarte, J. J.; Golvano, J.; Gullon, A.; Civeira, M. P.; Prieto, J.; Borrascuesta, F. Induction of Antibodies Against A Peptide Hapten Does Not Require Covalent Linkage Between the Hapten and A Class-Ii Presentable T-Helper Peptide. Eur. J. Immunol. 1991, 21 (6), 1555-1558.

(50) Partidos, C. D.; Obeid, O. E.; Steward, M. W. AntibodyResponses to Nonimmunogenic Synthetic Peptides Induced by Coimmunization with Immunogenic Peptides. Immunology 1992, 77 (2), 262-266.

(51) Brons, N. H. C.; Blaich, A.; Wiesmuller, K. H.; Schneider, F.; Jung, G.; Muller, C. P. Hierarchic T-cell help to non-linked B-cell epitopes. Scand. J. Immunol. 1996, 44 (5), 478-484.

(52) Shaw, D. M.; Stanley, C. M.; Partidos, C. D.; Steward, M. W. Influence of the T-Helper Epitope on the Titer and Affinity of Antibodies to B-Cell Epitopes After Co-Immunization. Mol. Immunol. 1993, 30 (11), 961-968.

(53) Van Regenmortel, M. H. What is a B-cell epitope? Methods Mol. Biol. 2009, 524, 3-20.

(54) Arnon, R.; Van Regenmortel, M. H. Structural basis of antigenic specificity and design of new vaccines. FASEB J. 1992, 6 (14), 32653274.

(55) Barlow, D. J.; Edwards, M. S.; Thornton, J. M. Continuous and discontinuous protein antigenic determinants. Nature 1986, 322 (6081), 747-748.

(56) Van Regenmortel, M. H. V. Mapping Epitope Structure and Activity: From One-Dimensional Prediction to Four-Dimensional Description of Antigenic Specificity. Methods 1996, 9 (3), 465-472.

(57) Lin, J.; Sampson, H. A. The role of immunoglobulin E-binding epitopes in the characterization of food allergy. Curr. Opin. Allergy Clin. Immunol. 2009, 9 (4), 357-363.

(58) Bannon, G. A.; Ogawa, T. Evaluation of available IgE-binding epitope data and its utility in bioinformatics. Mol. Nutr. Food Res. 2006, 50 (7), 638-644.

(59) Albrecht, M.; Kuhne, Y.; Ballmer-Weber, B. K.; Becker, W. M.; Holzhauser, T.; Lauer, I.; Reuter, A.; Randow, S.; Falk, S.; Wangorsch, A.; Lidholm, J.; Reese, G.; Vieths, S. Relevance of IgE binding to short peptides for the allergenic activity of food allergens. J. Allergy Clin. Immunol. 2009, 124 (2), 328-36336.

(60) Halassy, B.; Mateljsak, S.; Bouche, F. B.; Putz, M. M.; Muller, C. P.; Frkanec, R.; Habjenec, L.; Tomasic, J. Immunogenicity of peptides of measles virus origin and influence of adjuvants. Vaccine 2006, 24 (2), 185-194. 